\title{
WWII German Military Structures in Angers (FR)
}

\author{
Giancarlo T. Tomezzoli \\ Etno-Archaeological Observatory, Munich, Germany \\ Email: gt21949@gmx.de
}

How to cite this paper: Tomezzoli, G. T. (2018). WWII German Military Structures in Angers (FR) Archaeological Discovery, 6, 300-318.

https://doi.org/10.4236/ad.2018.64015

Received: August 2, 2018

Accepted: September 14, 2018

Published: September 17, 2018

Copyright (C) 2018 by author and Scientific Research Publishing Inc. This work is licensed under the Creative Commons Attribution International License (CC BY 4.0).

http://creativecommons.org/licenses/by/4.0/

\section{(c) (7) Open Access}

\begin{abstract}
In previous publications, some WWII German military structures around Angers (FR): at Mûrs-Érigné, the Domaine de Pignerolle and Bouchemaine, during the German Occupation period were described and analyzed. The discovery in 2014 in a private archive of a French Resistance map dated 1942 showing further German military structures on the right side of the Maine and a plan of a large bunker in La Reux at Saint-Barthelemy d'Anjou forced the resumption of the researches about German military structures in the Angers sector. The Angers sector retreated from other WWII German more sensitive military sectors in France and less exposed to allied air attacks, offered for a quite long time, during the Occupation, a quiet place for developing military activities. The visits on the sites permitted, at about seventy years from the end of the WWII, to better understand the purpose and estimate the preservation state of the surviving structures.
\end{abstract}

\section{Keywords}

WWII, Occupation, Atlantic Wall, Pignerolle, Saint-Pierre, V149, UCO, R 608, La Reux, Bessonneau, Angers, France

\section{Introduction}

Angers, in North-West France, played during the WWII an important role as witnessed by German military structures erected at of Mûrs-Erigné (Suquet, 2010; Tomezzoli, 2016), the Domaine de Pignerolle (Tomezzoli et al., 2013) and Bouchemaine (Tomezzoli, 2018). It was the discovery on 2014 in a private archive of a French Resistance map dated November and December 1942, prepared for the Central Office of Information and Action (BCRA-Bureau Central de Reinseignement et Action) in London showing further German military structures on the right side of the Maine and the plan of a large bunker in La Reux at 
Saint-Barthelemy d'Anjou that forced the resumption of the researches about the German military structures in Angers in the period of the Occupation with the integration of materials collected in the past.

\section{Angers during the WWII}

After the Polish army defeat in September 1939, the higher Polish authorities decided to exile. In crossing Romania, under German diplomatic pressure, the Polish president Mr. Moscicki, the ministers, the chiefs of the army and all the soldiers present were interned. The president Moscicki, in the impossibility of exercising his functions, according to the Polish constitution, appointed as new president the vice-president Mr. Raczkiewicz, who appointed the army general Mr. Sikorski as prime minister of the Polish government in exile.

Angers was selected by the French authorities as site of the new Polish president and government in exile and the foreign accredited ambassadors, including a French ambassador. The Pignerolle castle at Saint-Barthelemy d'Anjou was assigned as residence to president Raczkiewicz, who took possession on 2nd December 1939.

The rapid German invasion of France on June 1940 obliged, on 12th June, the Polish president and government to leave Angers for Great Britain through Spain. An English headquarters took then place at the castle for only two days (Lemesle, 1974).

Angers was invaded by refugees coming from Belgium, Luxembourg and North France escaping the German invasion. Civilian and religious establishments were requisitioned and the Red Cross, the Scouts and most part of the Angers population organized themselves for their aid. The town population grew up rapidly from 88,000 to 100,000 inhabitants, and in order to satisfy the needs of the increased population and because of the war restrictions on the supplies, the municipality provided to ration the provision by introducing the food cards.

The French army, faced to the German invasion retreated in disorder, sometime opposing a valid resistance, as the cadets of the Saumur cavalry school on 19th-21st June. Angers suffered various German Air Force (Luftwaffe) bombings. On 14th June the Avrille airfield was hit and on 17th June the rail stations of Saint Serge and Saint Loud were hit. In this last about twenty Senegalese soldiers of the 27th Colonial Mixed Infantry Regiment were killed. Overall, thirty killed and thirty wounded were registered in the districts of the two rail stations. Because of the bombings about 20,000 inhabitants leaved the town to be relocated South to the Loire (Lemesle, 1981; Lemesle, 1996).

On 19th June at about 8:30 a.m. German troops arrived at La Flèche, $50 \mathrm{~km}$ from Angers. From a post office, a German commander menaced the municipality of intensive bombings in case of Angers defense. The mayor and the prefect of Angers informed about the German menace general Langlois, responsible of the Angers defense who intended to resist. But at 11:00 a.m. he received the 
authorization to declare Angers open city. Later, the mayor, the prefect and a military representative went to Seiches-sur-Loir, $20 \mathrm{~km}$ from Angers, giving guarantee to the Germans about the non-defense of Angers. At 15:00 p.m. the German troops entered in Angers without accidents. On 20th June Angers was taken over by general von Boeckmann commander of the Angers occupation corps and his headquarters, which went to the city hall and hoisted on the facade the German swastika flag (Lemesle, 1996).

After the Occupation, Angers was seat of the Military Administration-Zone B (Militärverwaltung-Zone $B$ ), for which a great portion of the buildings of the West Catholic University (UCO-Université Catholique de l'Ouest), 10 big school buildings and 280 other buildings were requisitioned. Part of the hospital and all the military establishments were equally requisitioned. The Angers castle hasted an ammunition depot and headquarters of the German Land Army (Heer) veterinary services.

The Avrillé airfield was requisitioned and adapted, by requisitioned civilians, for fighters and night bombers during the Battle of Britain. The War Navy (Kriegsmarine) on 8th July requisitioned the castle and the Domaine de Pignerolle at Saint Barthelemy d'Anjou to install the Commander (Befehlshaber) of $U$-Bootes and his headquarters, the castle and Domaine of Saint-Pierre at Mûrs-Érigné to install the Kriegsmarine Atlantic Coast (Atlantikkuste) headquarters (Lemesle, 1996; Coiffard, 2006; Suquet, 2010; Tomezzoli et al., 2013) and the castle and the Domaine de La Doubinière for install a logistic base popularly named "The Bank” (Tomezzoli, 2016).

The Heer withdrew from Angers between 1st-6th August 1944 leaving on place some combat groups. The 5th Infanterie Division US Red Diamond freed Angers on 10th August and the Angers district on 1st September.

\section{The Map $\mathrm{N}^{\circ} 200 \mathrm{~b}$}

The map $\mathrm{N}^{\circ} 200 \mathrm{~b}$, scale $1 / 20,000$ (Figure 1) was prepared on November-December 1942 by the communist French Resistance in Angers and sent to the $B C R A$ in London. It shows German military structures in Angers on the right side of the Maine. The accompanying explicatory sheet $\mathrm{N}^{\circ} 510$, mentioned in the map is, unfortunately, lost.

The map is a copy of an original preserved at the Musée de la Resistance $d$ Ivry and identifies the following military structures:

(1) Point E, important house and barrack camp under a wood

(2) Point G

(3) Transformer

(4) Camouflaged air fuel reservoirs of large capacity

(5) Post A

(6) Underground German place

(7) Projectors

(8) Underground 


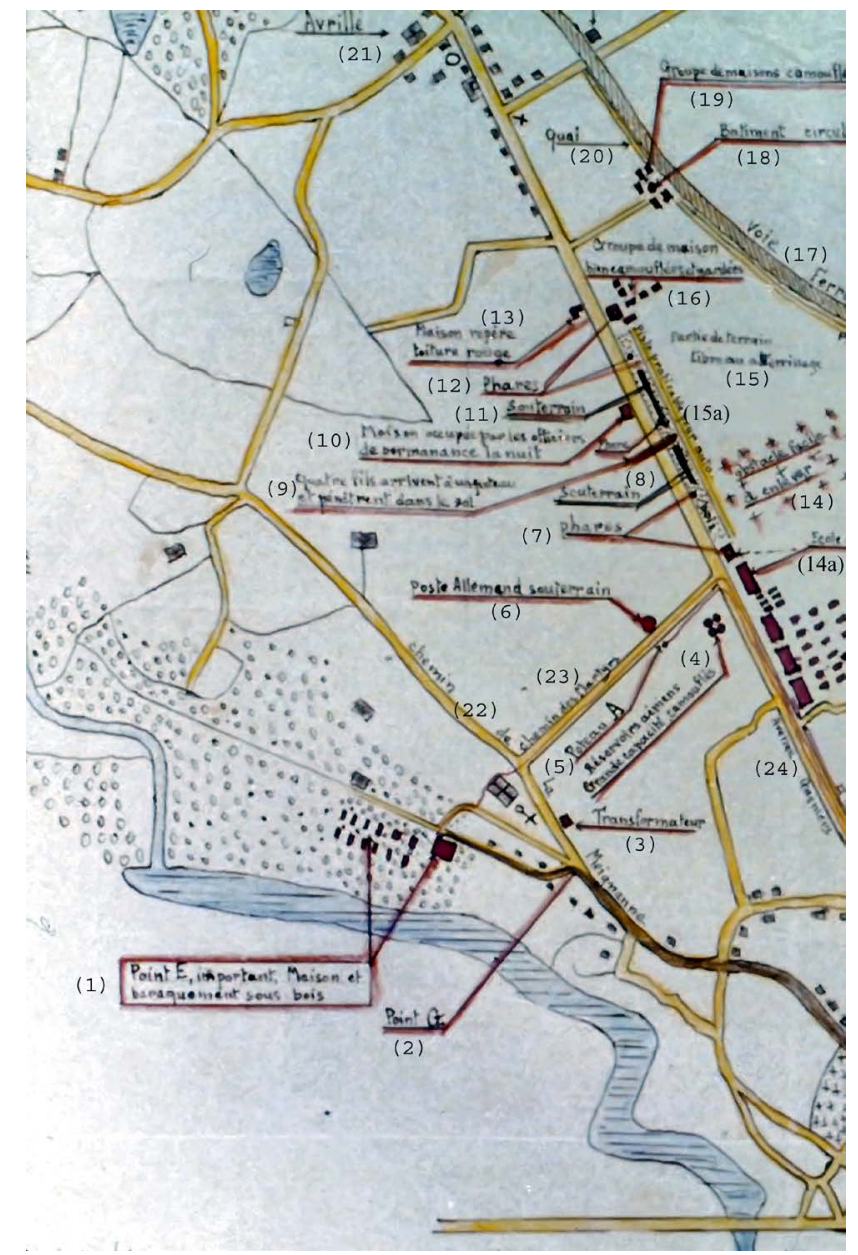

(A)

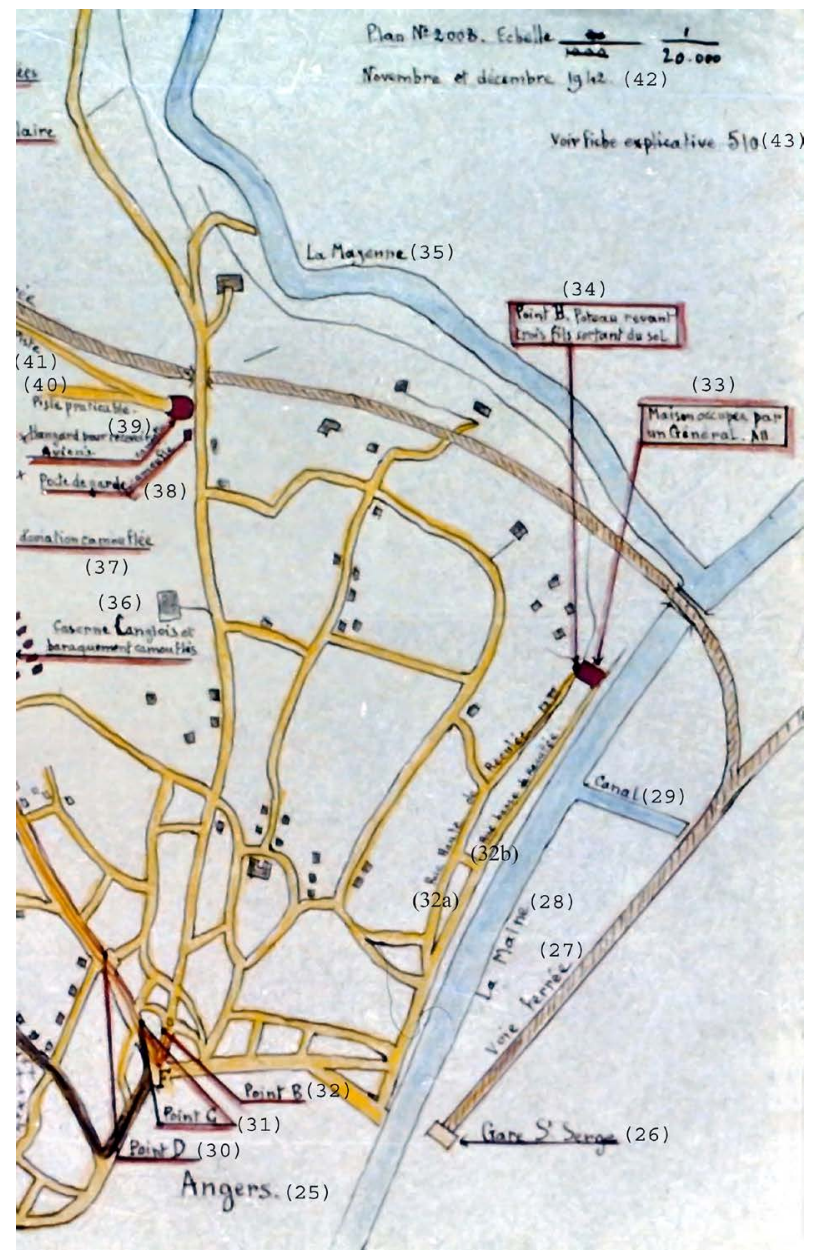

(B)

Figure 1. Map N² 200b: (A) west portion; (B) east portion (courtesy M. Letertre).

(9) Four cables arrive to a post and penetrate the soil

(10) House occupied by the night duty officers

(11) Underground

(12) Projectors

(13) Landmark house, red painted

(14) Obstacle easy to enter

(14a) School

(15) Portion of land free for landing

(15a) Practicable track for cars

(16) Group of well camouflaged and guarded houses

(17) Railway track

(18) Circular building

(19) Group of camouflaged houses

(20) Dock

(21) Avrillé

(22) Chemin de la Mayenne

(23) Chemin des Martyrs 
(24) Avenue Gasniers

(25) Angers

(26) Rail station St. Serge

(27) Railway track

(28) Maine river

(29) Canal

(30) Point D

(31) Point C

(32) Point B

(32a) Rue Haute de Reculée

(32b) Rue basse de Reculée

(33) House occupied by a German general

(34) Point $\mathrm{H}$ Post raising three cables coming out of the ground

(35) Mayenne river

(36) Barrack camp Langlois and camouflaged barrack camp

(37) Camouflaged Aviation School

(38) Camouflaged guard post

(39) Camouflaged hangar for aircrafts

(40) Practicable runway

(41) Runaway

(42) Map N²00b. Scale 1/20,000 November and December 1942

(43) See explanatory sheet 510

Figure 2 shows structures that survived undamaged the allied bombardments on Angers of 17 June 1944.

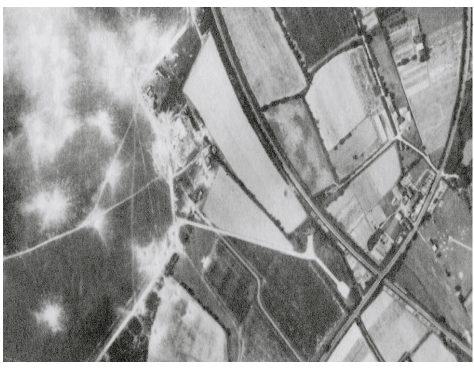

(A)

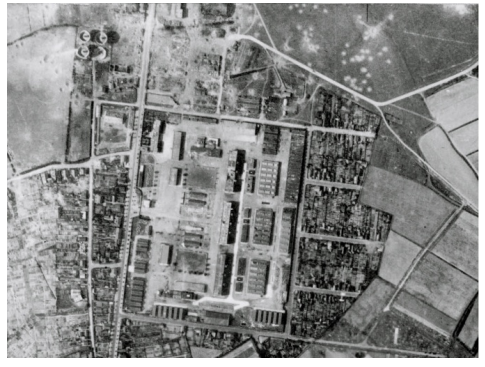

(B)

Figure 2. Structures survived the bombardments: (A) structures (39)-(41)-C1522-0421_ 1944_US7GP2926_2016, n²016, 1/9974, Argentique, 14/08/1944; (B) structures (4) (36)-C1522-0421_1944_US/GP2926_2015, n²015, 1/9974, Argentique, 14/08/1944.

\section{V149 and Saint-Pierre Castle}

In winter 1942, the Kriegsmarine installed at Mûrs-Érigné the headquarters of the Kriegsmarine Atlantikkuste headed by Admiral E. Schirlitz. The headquarters comprised: Captain on Sea (Kapitäin zur See) O. Günther, Navy Artillery Captain (Käpitain Marineartillerie) Panzel, Frigate Captain (Fregattenkapitän) Braun Ditzen, Corvette Captains (Korvettenkapitäne) H. Müller, Nusche, Schaafhausen, Lieutenant. 
Commander (Kapitänleutnant) H. Hansen, Doctor Saby and some other hundred officers and soldiers (Suquet, 2009). They were installed at the Saint-Pierre castle, residence of the Admiral, the "Bank", the castles of Bessonneau $\left(47^{\circ} 28^{\prime} 16.2^{\prime \prime} \mathrm{N}, 0^{\circ} 32^{\prime} 19.51^{\prime \prime} \mathrm{W}\right)$, Jau $\left(47^{\circ} 24^{\prime} 3.1^{\prime \prime} \mathrm{N}, 0^{\circ} 31^{\prime} 58.0^{\prime \prime} \mathrm{W}\right)$, Garenne $\left(47^{\circ} 24^{\prime} 13.0^{\prime \prime} \mathrm{N}, 0^{\circ} 31^{\prime} 52.4^{\prime \prime} \mathrm{W}\right)$ and other requisitioned properties in Mûrs-Érigné as the mansion "Ma Normandie" $\left(47^{\circ} 24^{\prime} 13.3^{\prime \prime} \mathrm{N}, 0^{\circ} 31^{\prime} 40.2^{\prime \prime} \mathrm{W}\right)$ at the entrance of the actual rue des Fusillés, which welcomed in its hotel-restaurant and luxury brothel also German officers serving in the Angers sector (Suquet, 2009).

A V149 (Figures 3-6) was built on 1943 at great urgency, day and night by the light of projectors, by the Brochard and Gaudichet firm of Angers under the

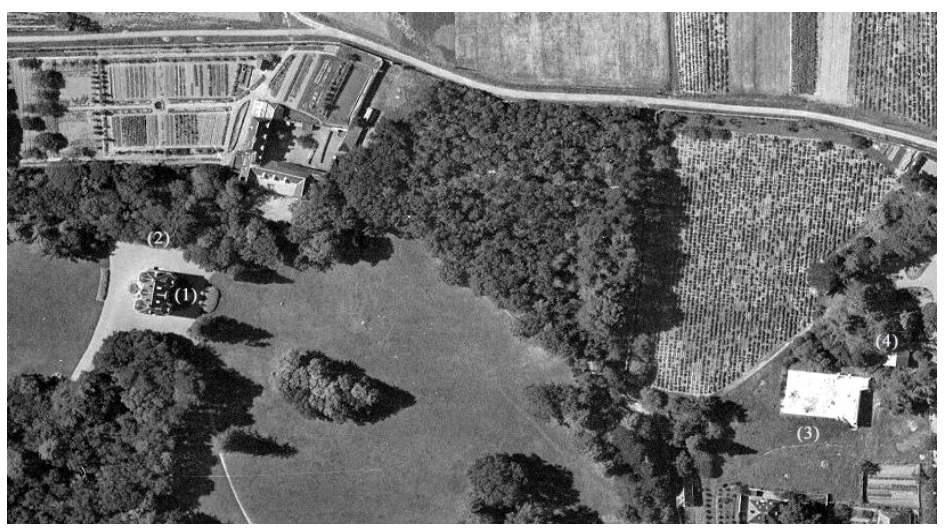

Figure 3. Kriegsmarine Atlantikkuste headquarters-(1) Saint-Pierre castle; (2) possible small bunker; (3) V149; (4) personnel lodgment barrack. C1522-0241_1948_CDP3038_ 0010, n 10, 1/4944, Argentique, 17/09/1948.

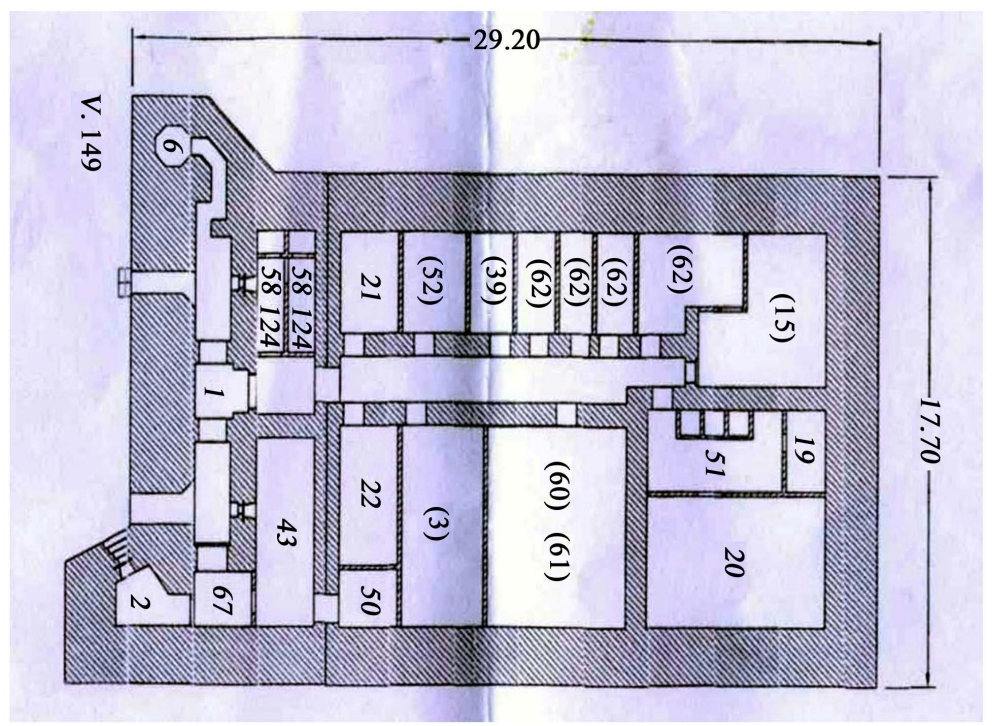

Figure 4. V149 plan-1 gas lock; 2 close combat room; 6 observation post; 19 wireless officer room; 20 wireless room; 21 heating room; 22 ventilation room; 43 engine room; 50 fuel room; 51 telephone exchange room; 58, 124 latrines/washrooms; 67 gear room (plan: P. Heijkoop); possible identification of the other rooms: (3) crew room; (15) charger room; (39) officers room; (52) telegraph room; (60) Naval Lieutenant room; (61) radio reconnaissance room; (62) work room (Rudi, 1988). 


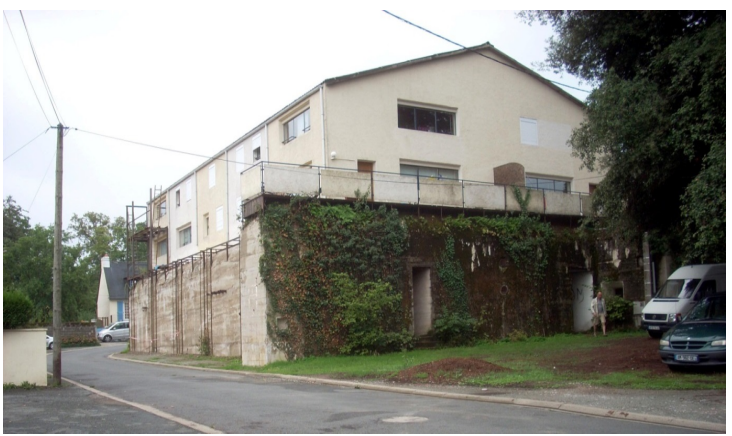

(A)

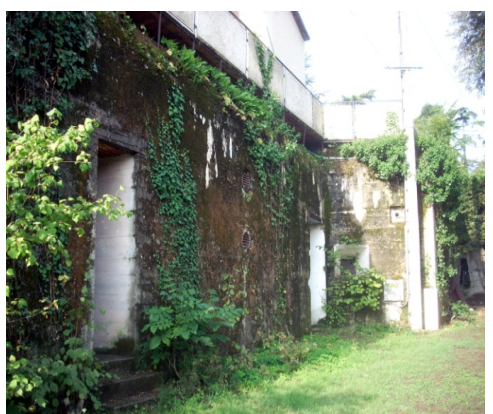

(B)

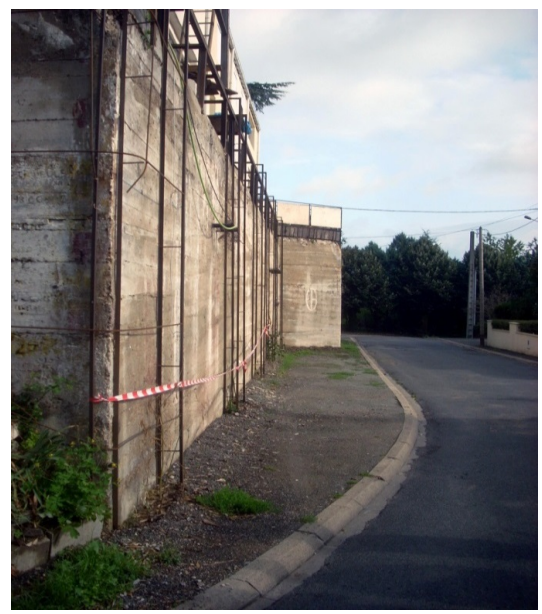

(D)

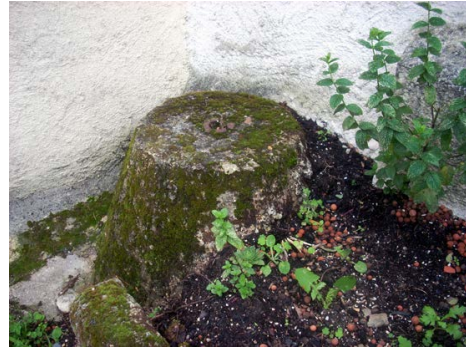

(F)

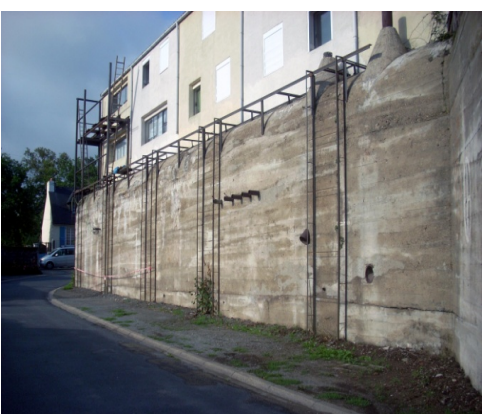

(C)

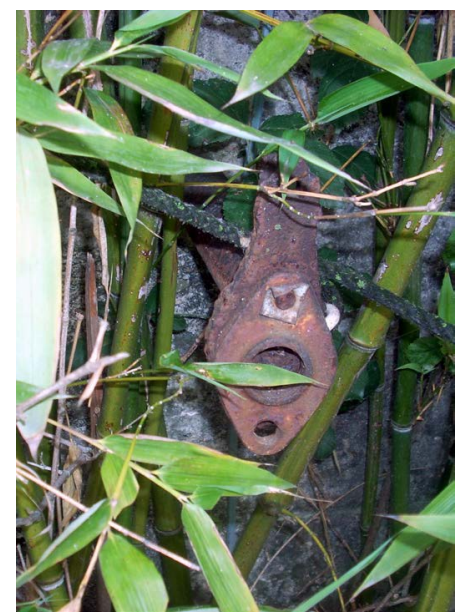

(E)

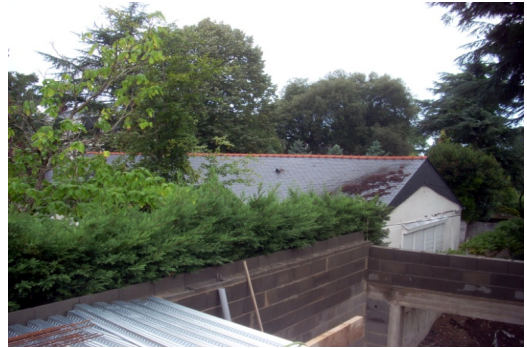

(G)

Figure 5. V149-(A) general view of V149 and superposed house; (B) facade covered by creeper plants and entrances-on the upper right opening of the close combat room; (C) external concrete structure with exits for the communication cables; (D) external concrete structure with oval white painted window as camouflage; (E) communication cable; (F) vertical antenna basement; $(G)$ renovated personnel lodgment barrack. 


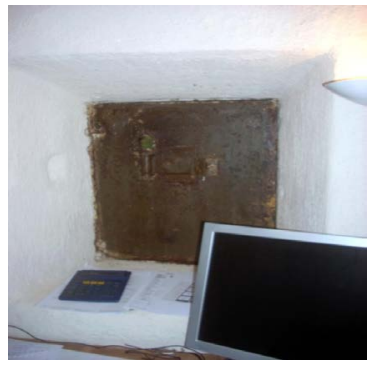

(A)

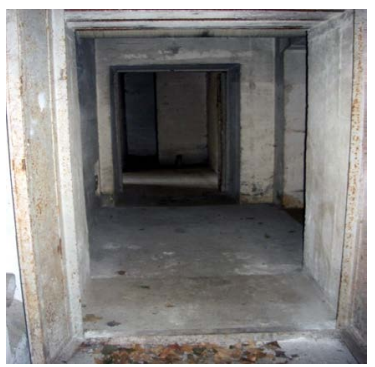

(C)

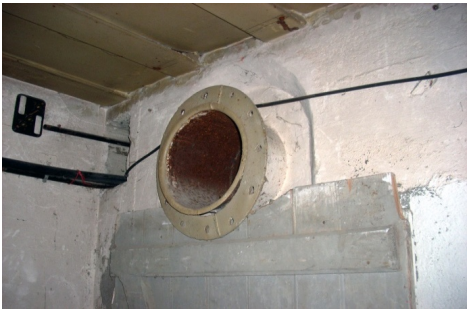

(E)

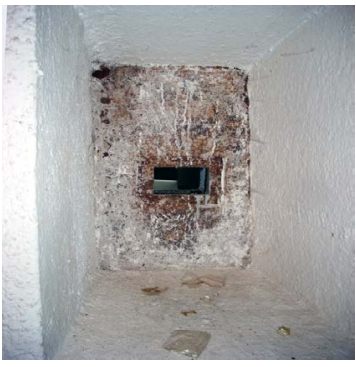

(B)

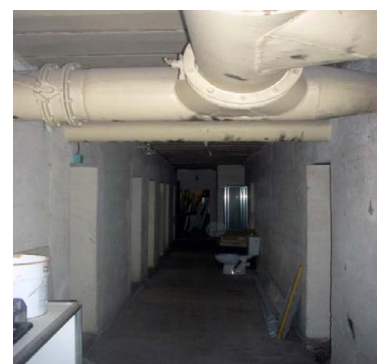

(D)

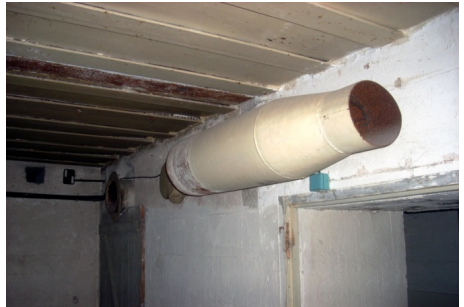

(F)

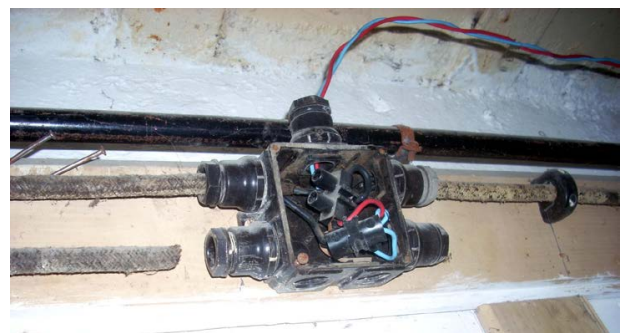

(G)

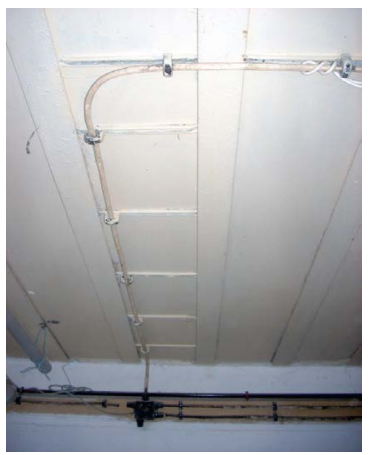

(H)

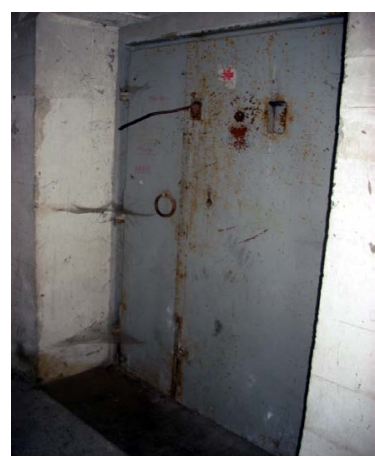

(I)

Figure 6. V149 interior-(A) close combat room, loophole plate; (B) internal loophole; (C) gas lock; (D) internal corridor; (E) and (F) ventilation conduits; $(\mathrm{G})$ and $(\mathrm{H})$ telephonic cables; (I) double sided door. 
direction of the Organization Todt (OT) Major Aderbach. The bunker permitted through its overhead, underground and wireless lines communications of the headquarters with the headquarters of the Befehlshaber der $U$-Boote at Pignerolle castle in Saint Barthelemy d'Anjou (Tomezzoli, Pottier, Marquet, \& Letertre, 2013) and by underground wired network with various other headquarters in Nantes, Rennes and Berlin via Paris. It assured also the radio links with the German surface ships based in the French Atlantic coast ports.

The visit of the $V 149\left(47^{\circ} 24^{\prime} 1.94 " \mathrm{~N}, 0^{\circ} 32^{\prime} 9.73^{\prime \prime} \mathrm{W}, 41.85 \mathrm{~m}, 42.08\right)$ took place on 19th September 2011. A white house with balcony occupied the whole V149 coverage. The visible V149 external concrete structure was in a good preservation state showing the traces of the construction formwork elements typical of the German masonry and no damages due to bombardments or combats. The internal walls preserved the original white color with re-painted portions and no traces of a thermal insulation system. The metallic ceiling preserved rusted portions and beige re-painted portions. Original, white painted conduit portions of the ventilation system were still at their place. All the original room furniture and electronic devices disappeared. Portions of electrical and telephone connections remained in place on the walls and ceiling. A renovated original personnel lodgment barrack was near the $V 149$ entrances.

The visit of the castle $\left(47^{\circ} 23^{\prime} 53.67^{\prime \prime} \mathrm{N}, 0^{\circ} 32^{\prime} 10.67^{\prime \prime} \mathrm{W}, 52.22 \mathrm{~m}\right.$ ) (Figure $7(\mathrm{~A})$ )

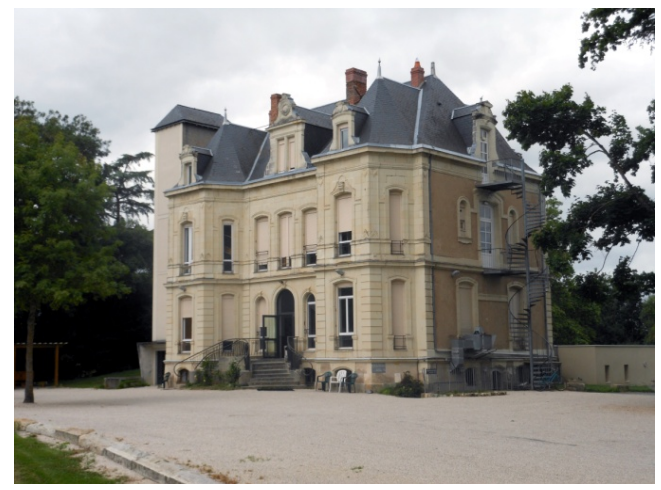

(A)

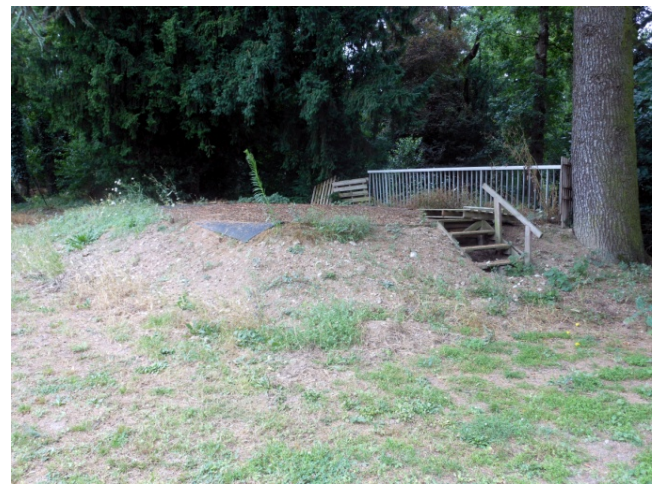

(B)

Figure 7. Kriegsmarine Atlantikkuste headquarters-(A) Saint-Pierre castle; (B) possible small underground bunker. 
took place on 30 July 2013. It hosted the Fraternité Chrétienne des Personnes Malades et Handicapées \& Association Gestion St. Pierre and Service aux Personnes organizations. The interior was renovated and nothing revealed its past function of Kriegsmarine Atlantikkuste headquarters. However, near the castle a mound $\left(47^{\circ} 23^{\prime} 53.45^{\prime \prime} \mathrm{N}, 0^{\circ} 32^{\prime} 11.57^{\prime \prime} \mathrm{W}\right.$ ) (Figure $7(\mathrm{~B})$ ) betrayed the possible presence of a small, about $5 \times 5 \mathrm{~m}$, buried bunker. The other castles and domains mentioned above are private residences not accessible to the public.

\section{The UCO R 608}

The presence of bunkers in the UCO campus was first mentioned by Mr. Suquet in 2009. Ms. Boumard, UCO Library conservator, on 2012 declared that on 1940 the Wehrmacht requisitioned all the university rooms, letting free only the university Palace in which the courses continued. After the German retreat, on the campus were found ash heaps, rests of tons of burned archived documents and two bunkers, one of the two, the bigger (Figures 8-10), was not possible to demolish and subsisted under the grass glaze which brings to the great teaching building (Bazin Palace) of Rabelais road (Figure 10).

The ash heaps of burned archived documents suggested for the bigger bunker a commandment place of the Heer. This hypothesis has been recently confirmed by the UCO students of the Association Mémoire Angevine, which localized $\left(47^{\circ} 27^{\prime} 45.68^{\prime \prime} \mathrm{N}, 0^{\circ} 32^{\prime} 47.32^{\prime \prime} \mathrm{W}\right)$, excavated and identified the bigger bunker as an $R$ 608: battalion regimental headquarters bunker on one floor.

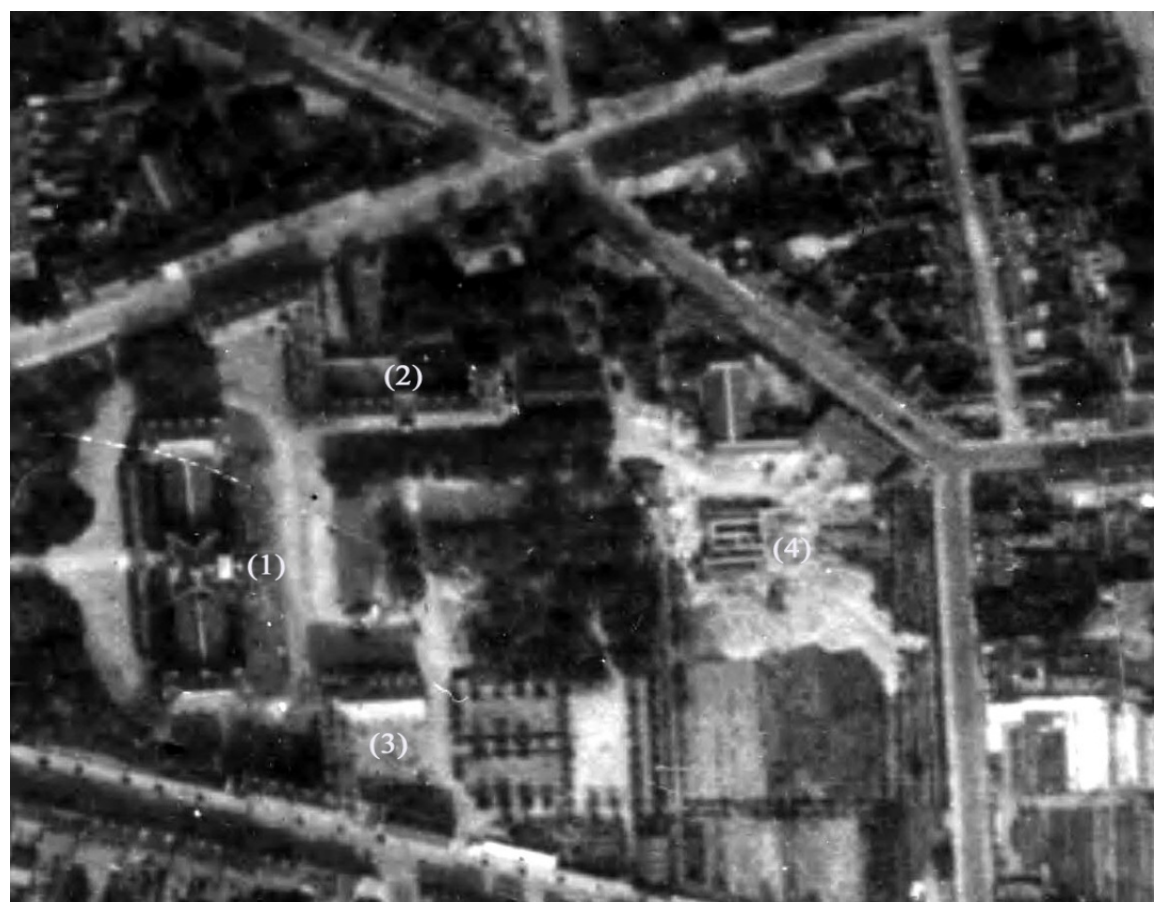

Figure 8. UCO campus-(1) university Palace; (2)-(3) university buildings; (4) excavation and R 608 C1522-0421_1944_US7GP2926_2021, n²012, 1/9980, Argentique, $14 / 08 / 1944$. 


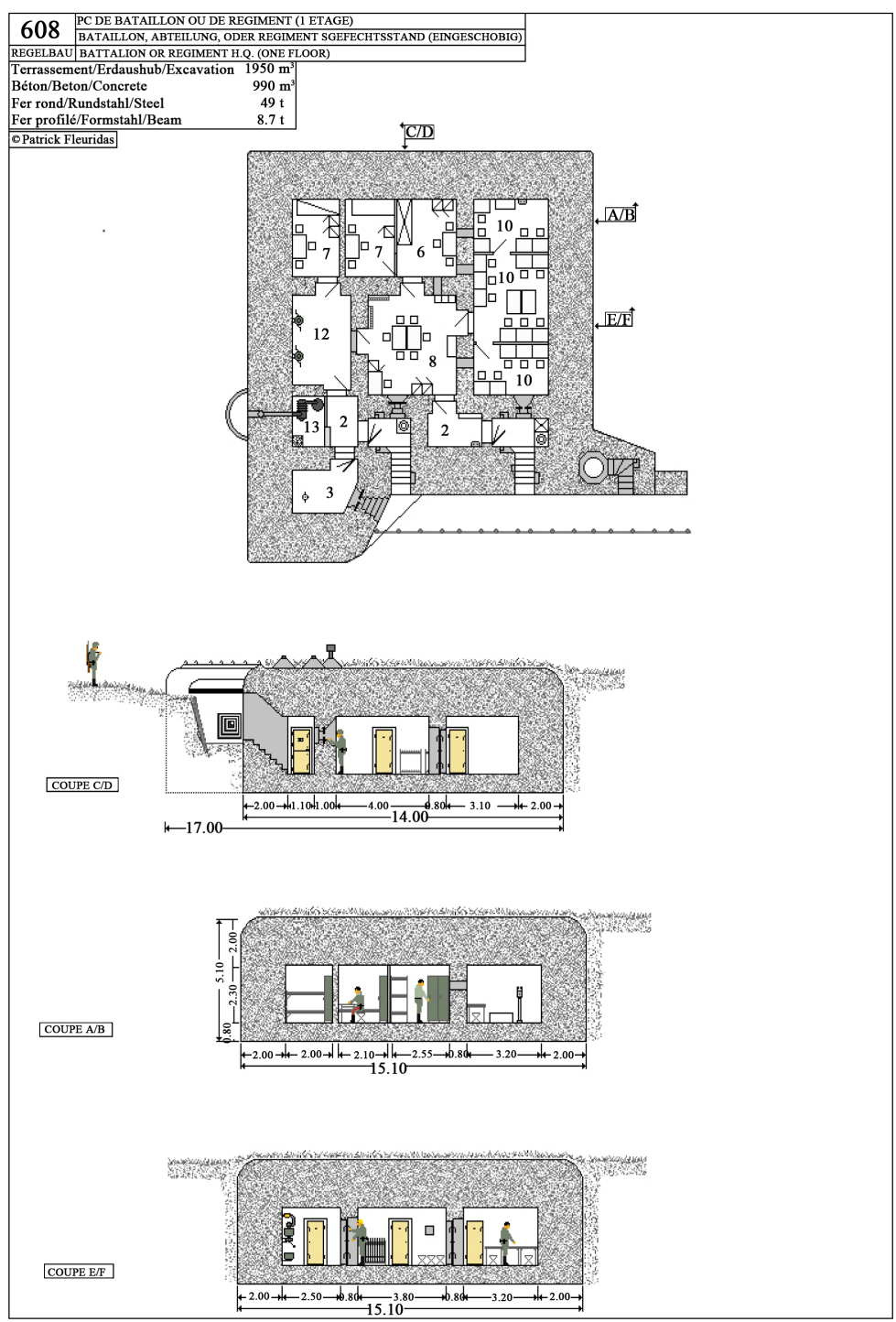

Figure 9. $R$ 608-(2) gaslock; (3) close combat room; (6) commander room; (7) crew room; (8) work room; (10) wireless/chart/plotting room; (12) ventilation room; (13) kitchen room (courtesy P. Fleuridas).

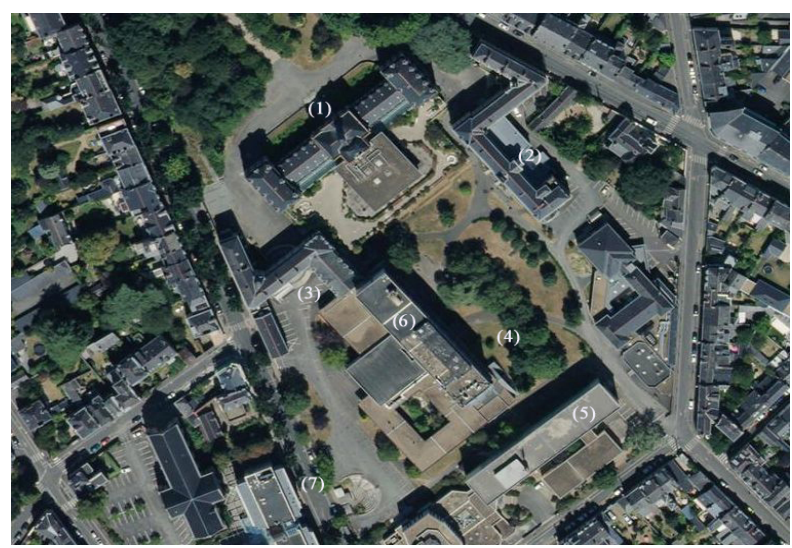

Figure 10. UCO campus-(1) University palace, (2)-(3) University buildings; (4) R 608; (5) Janneteau palace; (6) Bazin palace; (7) Rue Rabelais (Geoportail). 


\section{La Reux Bunker Complex}

Located at Saint-Barthelemy d'Anjou, in the locality La Reux, on one side of the actual Route d'Angers, about $2.6 \mathrm{~km}$ fat from the Domaine de Pignerolle, a bunker complex $\left(47^{\circ} 28^{\prime} 10.63^{\prime \prime} \mathrm{N}, 0^{\circ} 30^{\prime} 31.76^{\prime \prime} \mathrm{O}, 44.6 \mathrm{~m}\right)$ was composed by a 19.70 $\times 19.50 \mathrm{~m}$ main component, a $7.17 \times 10.55$ second component leaning against the main component and a $4.22 \times 7.40 \mathrm{~m}$ third component leaning against the second component (Figures 11-14).

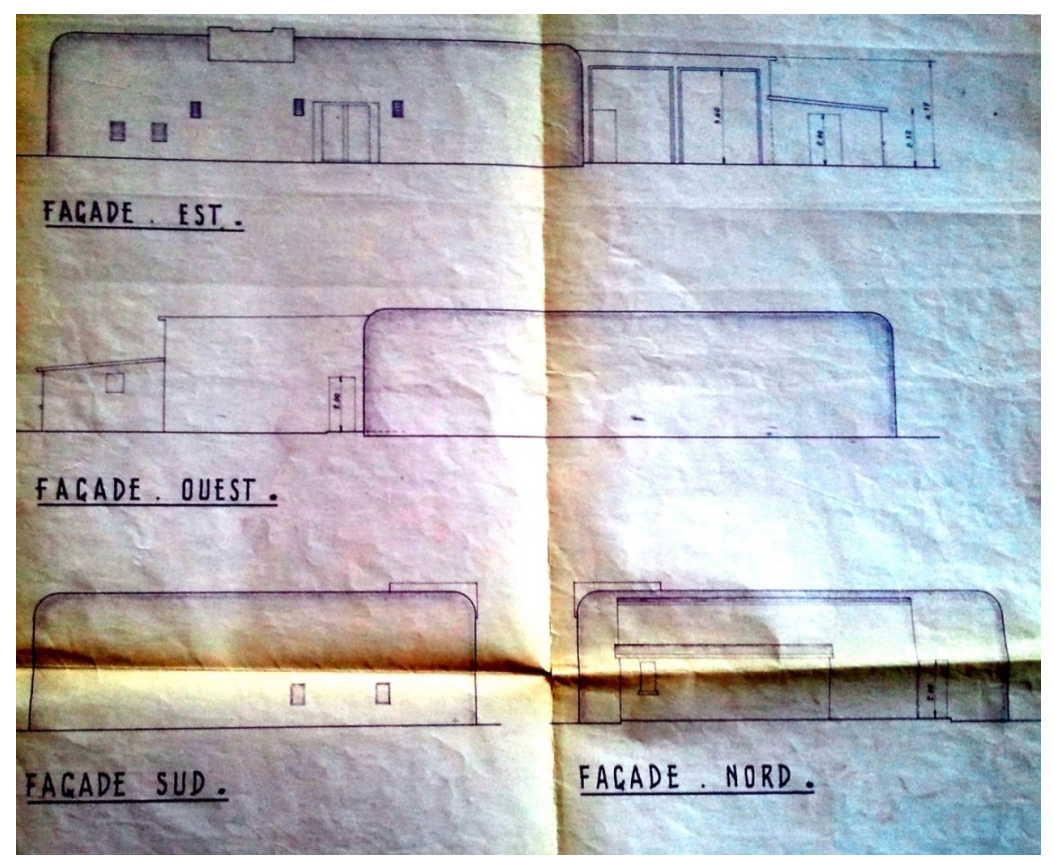

(A)

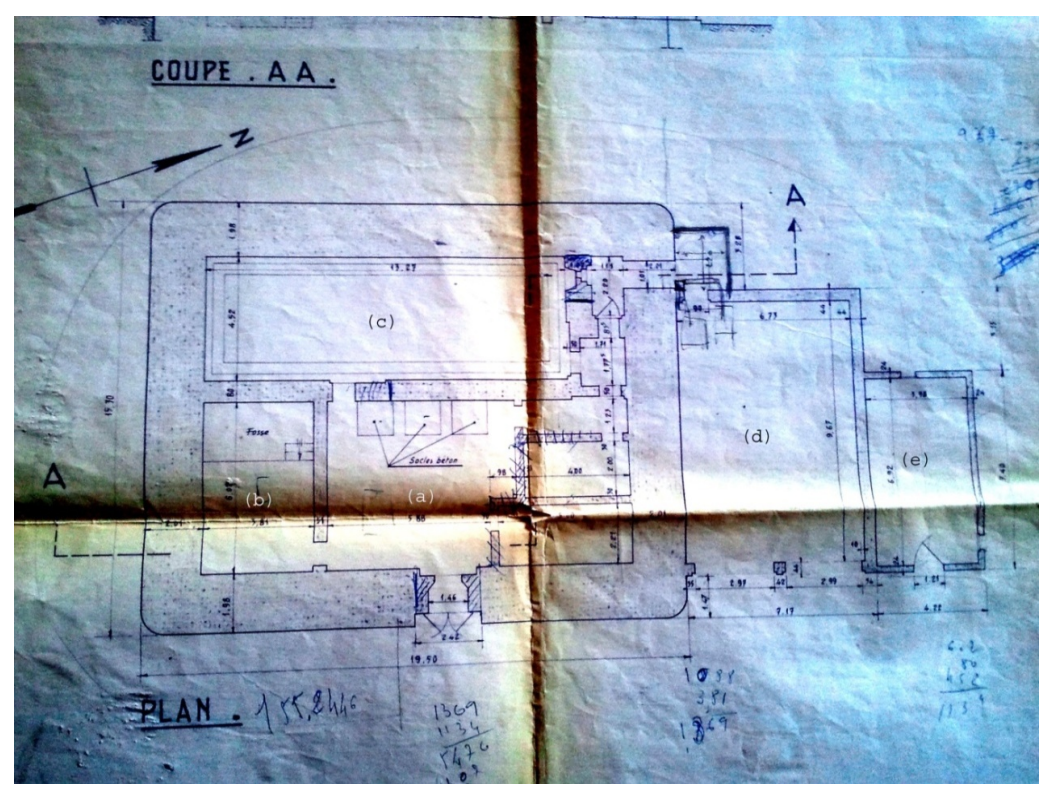

(B)

Figure 11. La Reux bunker complex-(A) external concrete structure; (B) plan: (a)-(c) rooms; (d) second component, (e) third component (courtesy M. Letertre). 


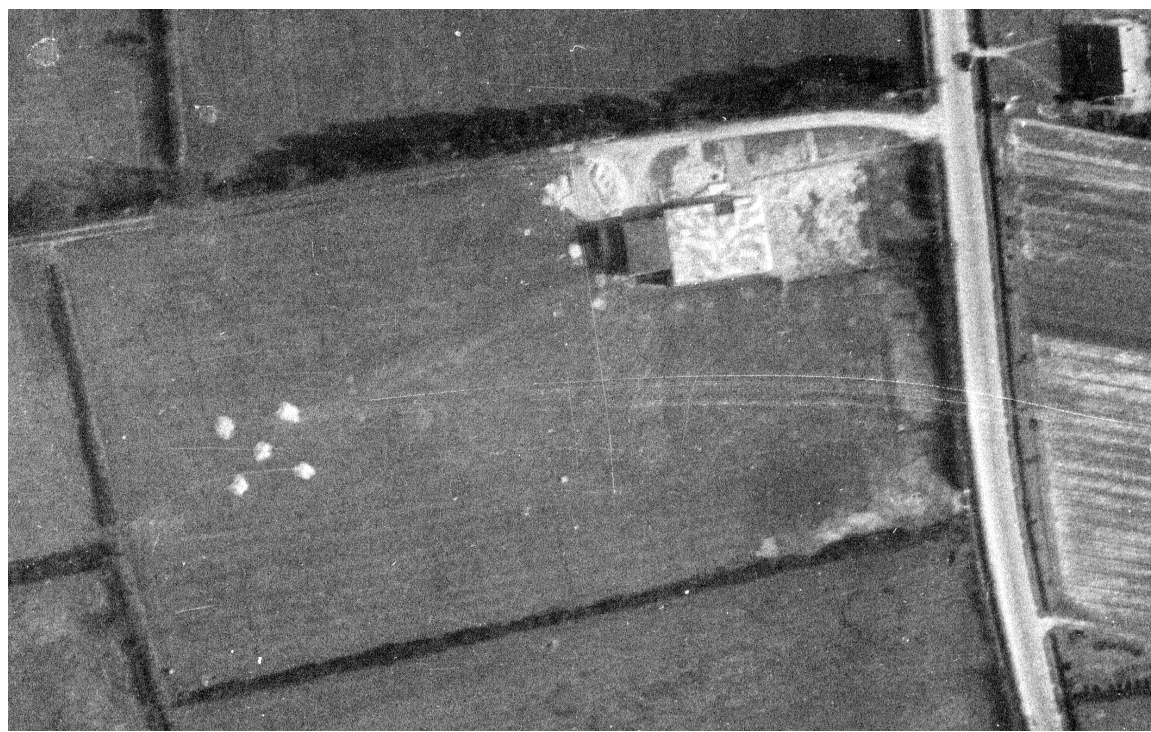

Figure 12. La Reux bunker complex-on the right bunker main component with camouflaged coverage, second and third components, on the left five antenna emplacements IGNF_PVA_1-0_1948-03-02__C1522-0501_1948_CDP2928_0385.

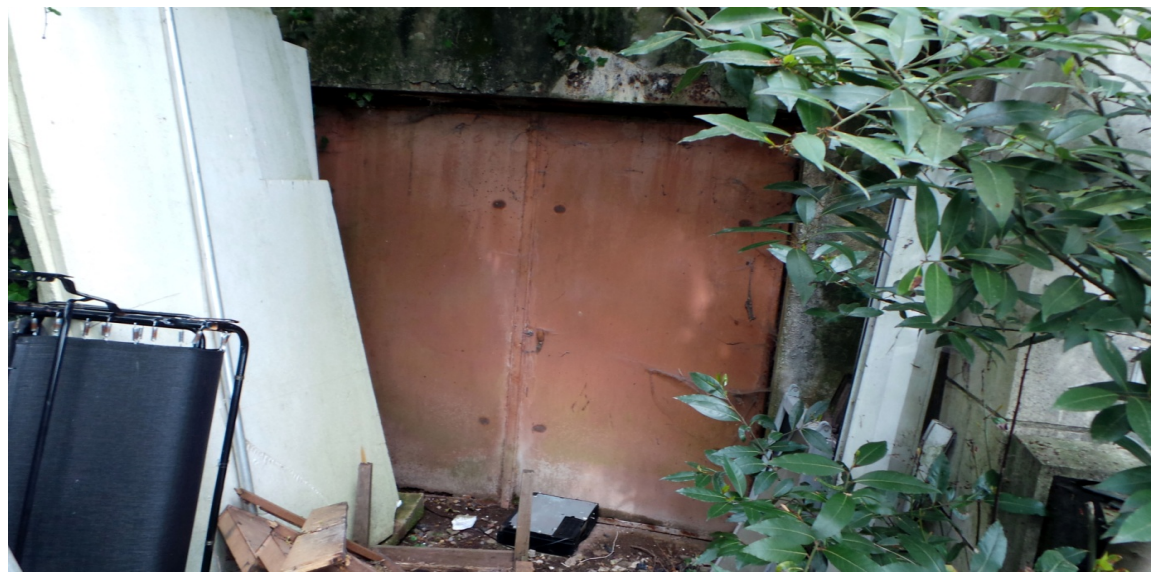

(A)

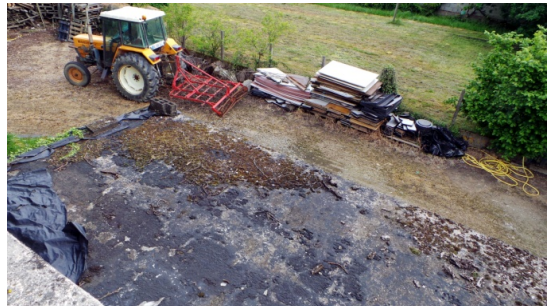

(B)

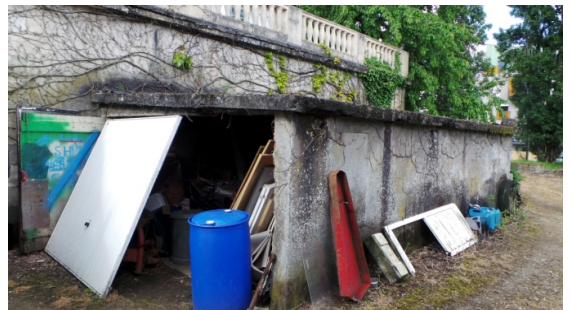

(C)

Figure 13. La Reux bunker complex-(A) main component, main entrance two-sided metallic door; (B) third component coverage; (C) third component side view.

The visit took place on 04th May 2014. Pieces of furniture, materials and creepers plants anywhere prevented an accurate determination of the preservation state of the external concrete structure, which, in general, appeared, for each component, in a good preservation state, without relevant damages due to 


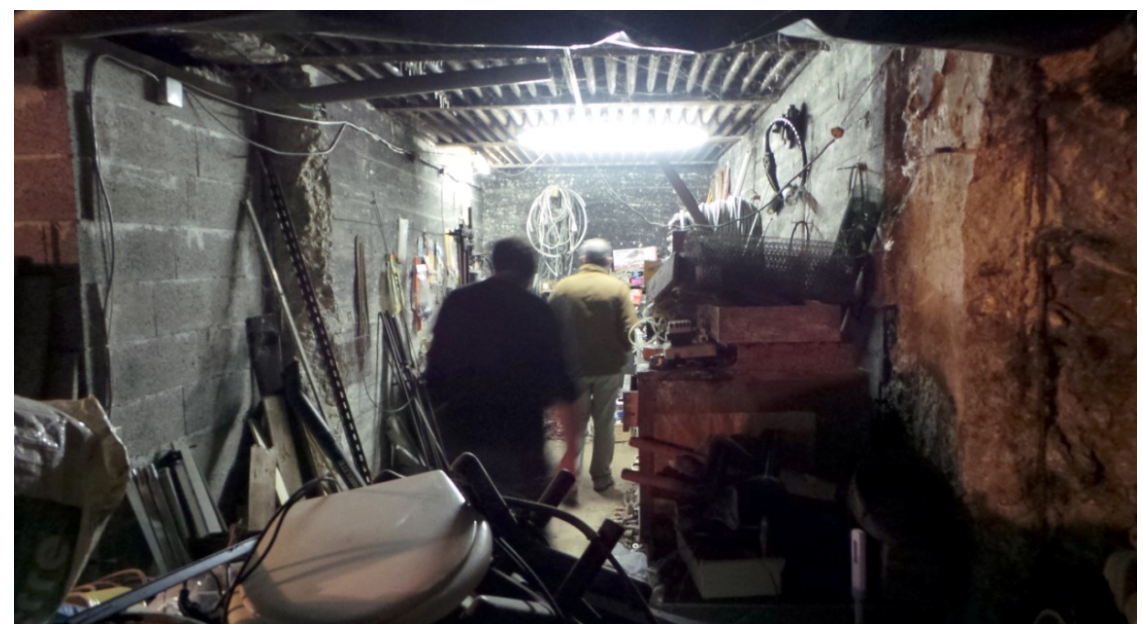

(A)

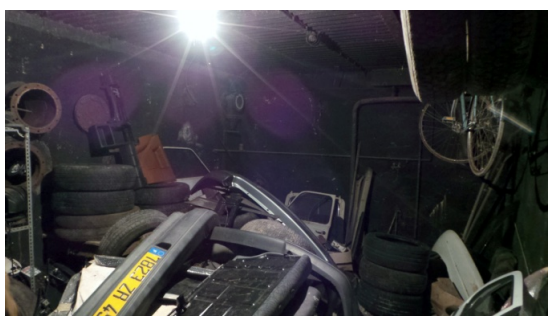

(B)

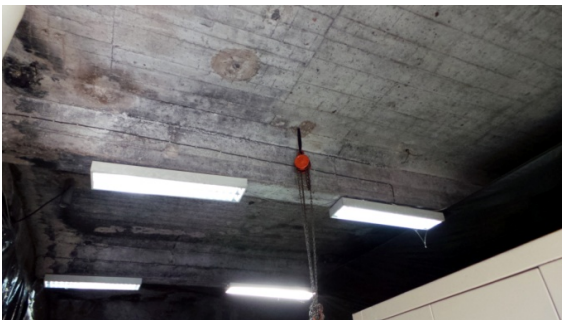

(D)

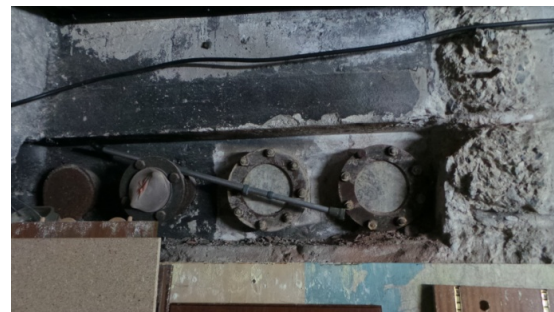

(F)

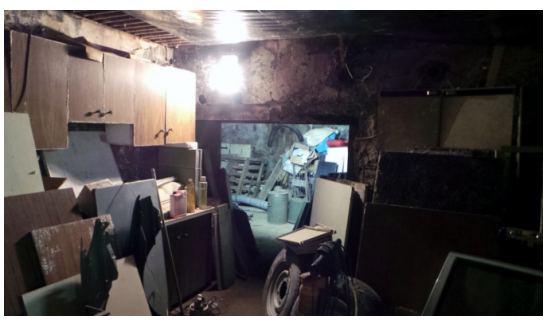

(C)

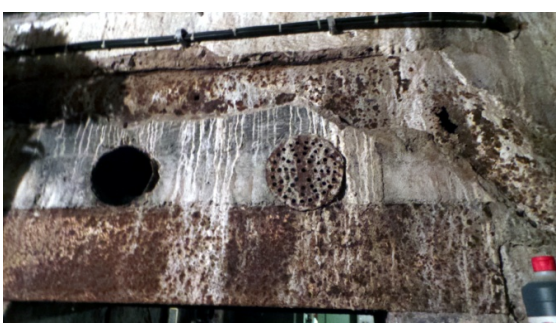

(E)

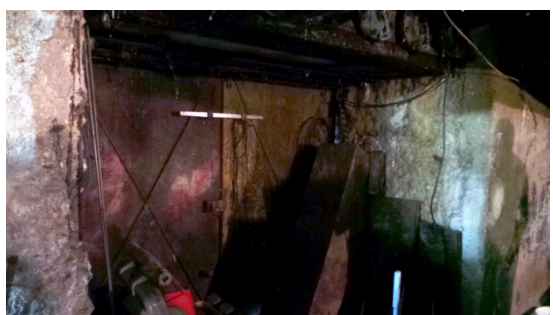

(G)

Figure 14. La Reux bunker complex-main component interior-(A) personnel access; (B) and (C) internal rooms encumbered by materials; (D) ceiling without metallic coverage; (E) and (F) ventilation conduits; (G) main entrance metallic door (courtesy M. Letertre).

bombardments or combats. The main component preserved the main entrance with its original, rusted two-sided metallic door and a personnel entrance on the adjacent side. Possible cable exits or antenna basements where not remarked. The internal inspection was possible through the personnel entrance. An incredible quantity of any kind of materials encumbered every room, preventing to 
distinguish possible rests of original furniture. However, apparently, all the original furniture and electric/electronic devices disappeared. Surprisingly, the ceiling had no metallic coverage letting visible the traces of construction formwork elements. Valves and part of ventilation conduits remained in place on the walls. A private house occupied a portion of the bunker coverage. The third component preserved on the coverage an external, tar insulation (Figure 13). The interior, of the second and third components, completely crowded by materials, were not accessible. Emplacements for five antennae in the nearby field (Figure 11) were occupied by modern constructions.

\section{Bessonneau Bunker}

The Bessonneau industry was the most important industry in Angers. On 1920 it employed 10.000 workers on 35 ha area for the production of canvases and ropes. During the Occupation it worked for the Germans and a bunker (Figure 15) was built near the castle for protecting, in case of attacks, the Kriegsmarine Atlantikkuste officers installed there. The workshop Ecce Homo, which grouped the weaving chains, was destroyed during the air bombardments of May 1944. Only the bunker survived the destruction of the industry (Robert, 2014).

The visit took place on 30th July 2013. The bunker in Angers, on the actual rue Louis Gain $\left(47^{\circ} 28^{\prime} 11.24^{\prime \prime} \mathrm{N}, 0^{\circ} 32^{\prime} 26.28^{\prime \prime} \mathrm{N}, 39.27\right)$ was completely masked by vegetation. Its external concrete structure (Figure 16) emerging from the terrain was in a good preservation state showing the traces of the construction formwork elements and no damages due to bombardments or combats. Two rusted metallic plates blocked the bunker entrance corridors, so that the internal inspection was not possible. However, looking through offset portions of the plates it was possible to ascertain that they preserved their original white paint. In one of them an original, rusty heavy metallic door $434 P O 1$ was still in place and metallic conduits were visible on the floor.

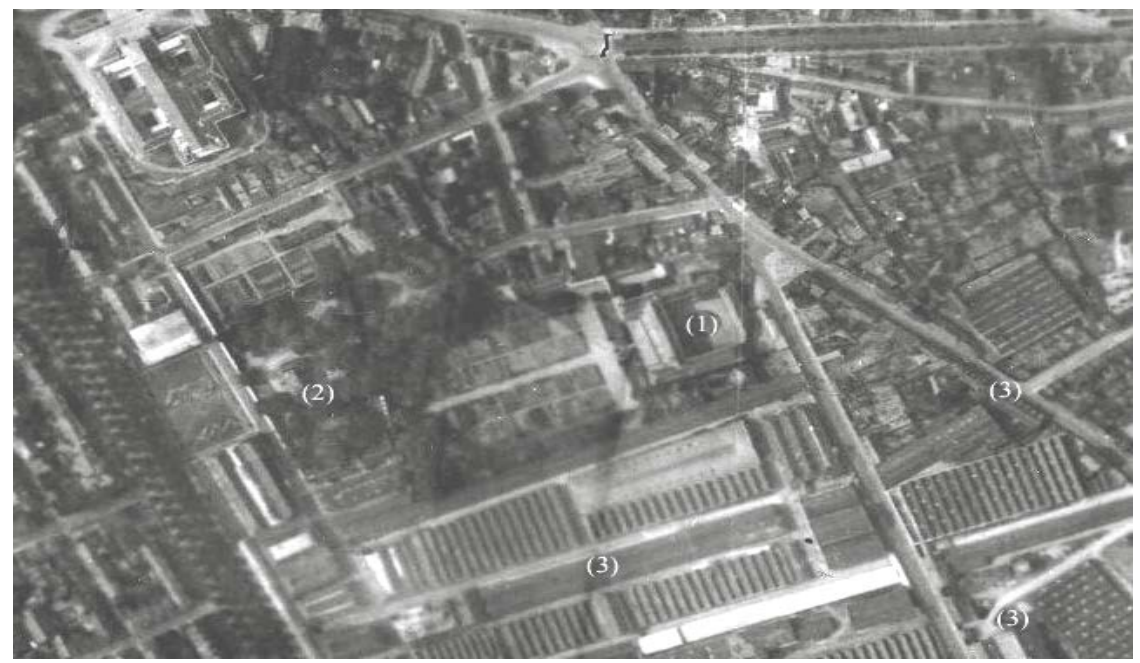

Figure 15. Bessonneau industry-(1) Bessonneau castle; (2) bunker; (3) industry sheds C1522-0421_1944_US7GP2926_2021, n²021, 1/9980, Argentique, 14/08/1944. 


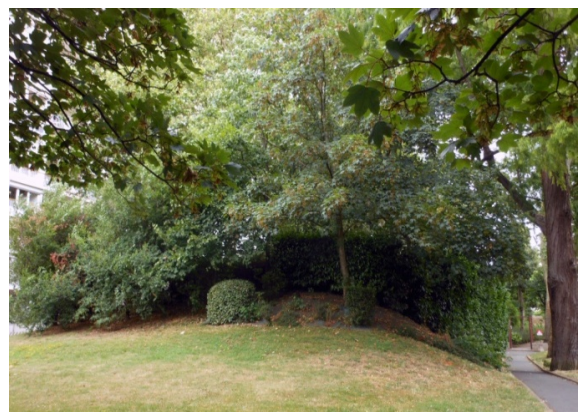

(A)

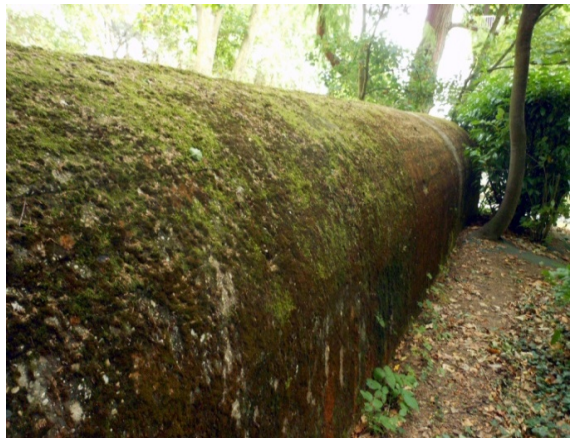

(C)

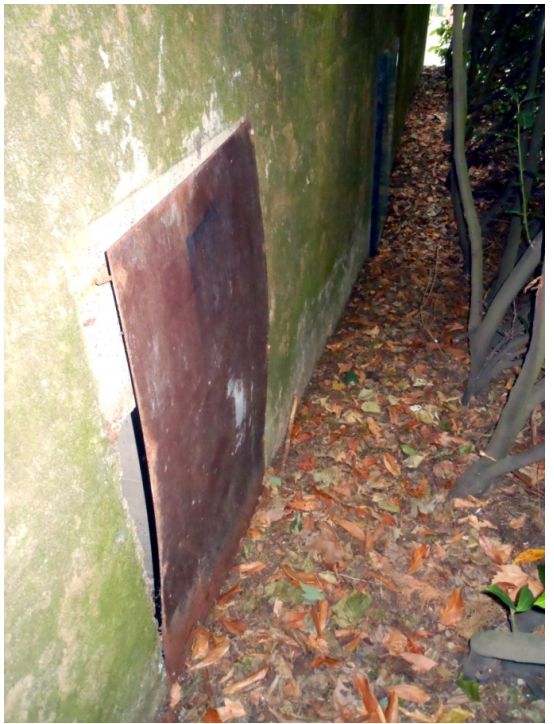

(E)

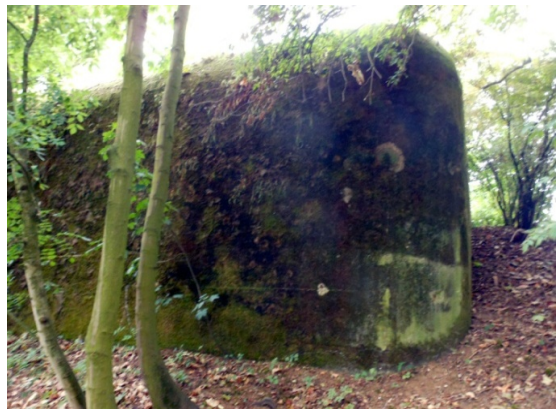

(B)

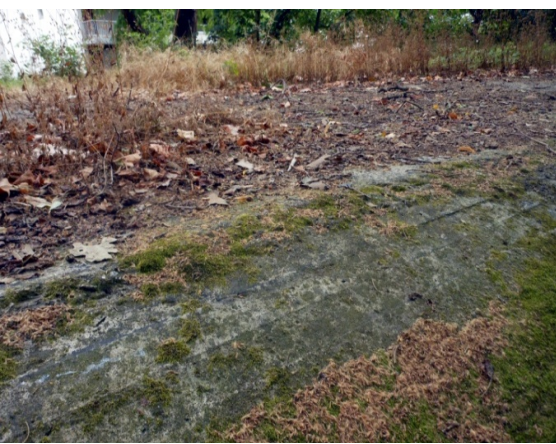

(D)

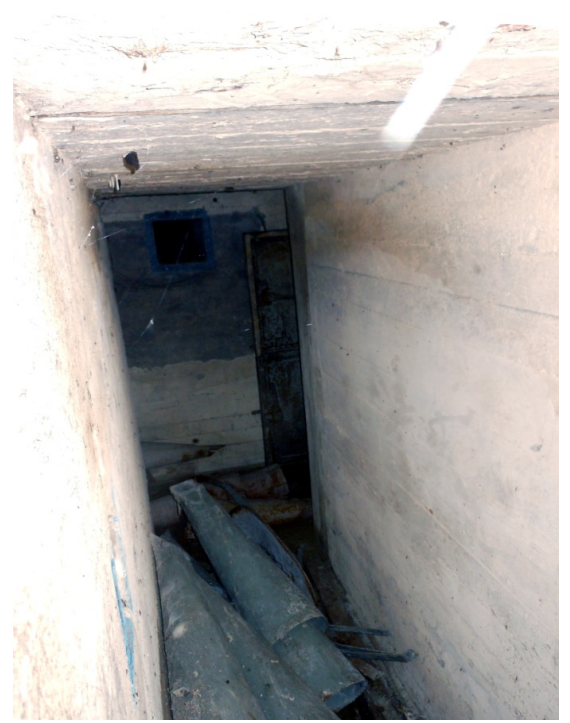

(F)

Figure 16. Bessonneau bunker-(A) exterior appearance; (B) and (C) external concrete structure; (D) coverage; (E) metallic plates blocking the entrances; (F) entrance corridor, on the top, louver of the close combat room, on the right rusty heavy metallic door $434 P O 1$, on the floor, metallic conduits.

\section{Discussion}

The attempt to access the original map $\mathrm{N}^{\circ} 200 \mathrm{~b}$ and the explicative sheet $\mathrm{N}^{\circ} 510$ at the Musée de la Resistance d IVry received, unfortunately no feedback. Point E (1) corresponds to the Parc de La Haye castle, bunkers, wood barracks and pool which hosted a radio jamming centre linked to the Befehlshaber der U-Bootes 
headquarters at Pignerolle. Officers were lodged in the castle and the personnel, comprising an important group of Wehrmacht female auxiliaries (Helferinnen) lodged in the wood barracks. Four nearby trenches about $10 \times 6 \mathrm{~m}, 2 \mathrm{~m}$ deep hosted copper cables emerging each two meters from water, probably part of the radio jamming system. After the war, French families escaped the bombardment of 17 June 1944 on Angers lodged in the wood barracks (Vincent, 2013). (6), (8), (11) correspond to bunkers, (9), (34) to communication lines, (7), (12) to projector emplacements for driving the anti-aircraft artillery (Flak) fire. Except for Point E, the absence of the explicative sheet $\mathrm{N}^{\circ} 510$ let the meaning and the importance of the Points B - D, H to be evaluated. Figure 2 shows two air recognition images taken immediately after the end of the Occupation and shows that the allied bombardments on Angers were not always effective because the structures (1), (4) (36), (39)-(41) corresponding respectively to the French camouflaged air fuel reservoirs, the barrack camp Langlois and the Avrillé airfield, dismantled in the years 70ts, remained intact.

The V149 was a bunker for the commander of MBTs (Schnellboote) considered suitable and adapted for the Kriegsmarine Atlantikkuste headquarters communications. Because of their military interest and sensitivity all the original V149 room furniture and electric/electronic devices were probably seized by the American and/or French military authorities. At the moment it is not possible to know which naval operations were coordinated through the V149.

The headquarters hosted by the UCO R 608 and the type and function of the smaller bunker, this last not visible in Figure 8, remain to be determined.

The main component of La Reux bunker complex (Figure 11(B)) was a special construction (Sonderkonstruktion) bunker having $1.98 \mathrm{~m}$ thick walls and coverage. The presence of a pit (fosse) in room (b) let suppose that there was hosted a fuel reservoir for one or more electrical (diesel) generators for electrical transformers located on the three square concrete basements (socles beton) in room (a). The purposes of room (c), $13.27 \times 4.52 \mathrm{~m}$, provided with combat louver toward the personnel entrance, and of the other bunker rooms remain to be determined. The extensions of rooms (a)-(c) and the thickness of walls and coverage let to think that the main component hosted sensitive, bulky and powerful generators, transformers and devices. A rectangular emplacement on the coverage near the main entrance (Figure 11(A) and Figure 12) hosted probably either a Flak gun or an antenna emplacement or the exhaust pipes of the generators. The generators and transformers were connected with the five antennae emplacement in the nearby field. Figure 12 shows that a paint camouflage was present on the coverage of the main component for increasing its safety, and fuzzy areas on the terrain near it and the second component (d) suggest areas covered by terrain removed during the foundation works. The second component (d), because of the two large, $3 \mathrm{~m} \times 3.60 \mathrm{~m}$, entrances and the site access road which directly leads to it (Figure 12), was a garage for at least two long vehicles, i.e. cistern or fire trucks. The third component (e) because of its $1.21 \mathrm{~m}$ 
narrow entrance and two windows was a personnel lodgement or a workshop. Its demolished front wall and actual walled windows (Figure 13(C)), with respect to the original plan, witnesses its adaptation as store after the war. The particular disposition of the five antennas at the corners and in the middle of a square area (Figure 12) let think that they were part of a radio goniometric system. Two other possible white dots near the component (e) indicate the possible presence of two other antennae (Figure 12). The kind of antennae is unknown. They and their basements were eradicated after the end of the war and before the 2nd March 1948. The kind of operations performed and which German unit led the bunker complex remain to be determined. Because of their military interest and sensitivity all the original electric/electronic devices were probably seized by the American and/or French military authorities. The private houses which occupy the coverages of the V149 and the coverages of the main component and second component (d) of La Reux bunker complex are not surprising, because other examples were already encountered in the Finistère (Tomezzoli \& Colliou, 2017).

Because of the absence of visible specific architectural elements, it was not possible to determine the Bessoneau bunker type. However according to the information received, the two entrance corridors communicate with a gas lock in which a single entrance introduces in a single room provided with two lowers protecting the two entrance corridors.

A further German bunker has been signaled in Angers at the locality La Chêne Ronde.

\section{Conclusion}

The precedent publications and the present article aid to better understand the organization of the German military presence in the Angers sector. However, they do only a portion of Angers city. Therefore, a further effort should be made for extending the search and identification of possible surviving German military structures in Angers areas not covered by said studies.

\section{Acknowledgements}

I thank very much Mr. M. Letertre for sharing the copy of the Map $\mathrm{N}^{\circ} 200 \mathrm{~b}$, the plan, the images of the interior of La Reux bunker and the information concerning the Bessoneau bunker, Ms. Boumard, UCO Library conservator, for her information concerning the UCO campus bunkers, Mr. Fleuridas for sharing the R 608 plan, Mr. Leclerc for the V149 plan and for his permission to visit this bunker and the proprietor of the La Reux bunker for his permission to Mr. Letertre to visit this bunker.

\section{Conflicts of Interest}

The author declares no conflicts of interest regarding the publication of this paper. 


\section{References}

Coiffard, J.-L. (2006). Domaine de Pignerolle-Témoin d'une grande Histoire. Angers Loire Tourisme: Château-Musee de la Communication.

Lemesle, M. (1974). L’Anjou des années 40. France: Les Editions du Choletais.

Lemesle, M. (1981). Angers sous l'occupation. Rennes: Ouest France.

Lemesle, M. (1996). 1939-1945 A travers l'Anjou. France: Les Editions du Choletais.

Robert, B. (2014). Rue Louis Gain, un bunker pour les officiers. Ouest France 28/07/2014. https://www.ouest-france.fr/pays-de-la-loire/angers-49000/rue-louis-gain-un-bunker-p our-les-officiers-2729927

Rudi, R. (1998). Typologie du Mur de l'Atlantique. Beetsterwaag, NUGI 923.

Suquet, G. (2009). Mûrs-Érigné et la Deuxième Guerre Mondiale (5è ed.). France: Suquet.

Suquet, G. (2010). D'Anger le Danger 1942-1945, Murs Érigné.

Tomezzoli, G. T. (2016). The German Base "The Bank" at Mûrs-Érigné (Anjou-FR). Archaeological Discovery, 4, 37-47. https://doi.org/10.4236/ad.2016.41004

Tomezzoli, G. T. (2018). Two French Oil Terminals in the WWII. Archaeological Discovery, 6, 196-215. https://doi.org/10.4236/ad.2018.63011

Tomezzoli, G. T., \& Colliou, S. (2017). The WWII Saint-Pabu German Radar Camp and the Stützpunkte Re 03, Re 04. Archaeological Discovery, 5, 142-162.

https://doi.org/10.4236/ad.2017.53009

Tomezzoli, G., Pottier, L., Marquet, C., \& Letertre, M. (2013) Les Installations de la Kriegsmarine au Domaine de Pignerolle. 39-45 Magazine, 60-72.

Vincent, H. (2013). Temoignage. La cité "des Baraquements" du parc de la Haye de 1944 à 1950. WikiAnjou. 10th March 2013.

https://www.wiki-anjou.fr/index.php/Avrill\%C3\%A9_-_Parc_de_la_Haye_Val_d\%27O r_P\%C3\%A9pini\%C3\%A8res 